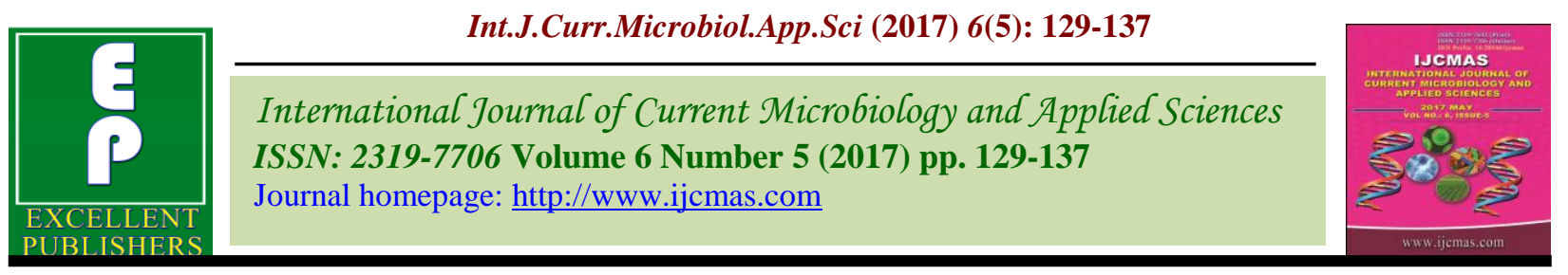

Original Research Article

https://doi.org/10.20546/ijcmas.2017.605.016

\title{
Comparative Study of Phytochemical Analysis, Antimicrobial and Antioxidant Activity of Different Root Extracts of Desmostachya bipinnata Stapf (Kush)
}

\author{
K.B. Joshi*, M.K. Mandavia and B.A. Golakiya \\ Department of Biochemistry and Biotechnology, Junagadh Agricultural University, \\ Junagadh, India \\ *Corresponding author
}

\section{A B S T R A C T}

The present study was designed to evaluate Preliminary phytochemical analysis, in vitro antimicrobial activity and antioxidant activity of different six extracts of Desmostachya Bipinnata Stapf (Kush). Plant roots were extracted in different six solvents viz. Hexane, ethyl acetate, acetone, Methanol, Water and Methanol: Water (90:10) through Soxtherm

Keywords

Desmostachya bipinnata Stapf,

Antimicrobial

activity,

Antioxidant activity, DPPH.

Article Info

Accepted:

04 April 2017

Available Online:

10 Mav 2017 according to polarity gradients. The phenolics, flavonoid, tannin and other phytochemicals of the extract were also determined using standard phytochemical reaction methods. Methanol: water and methanol extracts showed the presence of Phenol and glycosides, while in acetone extract terpenoids and glycosides were found. Aiming to investigate antimicrobial activities, agar well diffusion method was followed using three pathogenic bacteria and two fungi as test organisms. The plant root extracts showed moderate antibacterial activities (zone of inhibition (ZOI): 6-9mm) which was compared with standard kanamycin, while extracts showed positive antifungal activities (ZOI: 6-12 mm) and fluconazole was used as standard antifungal agent. We assessed the antioxidant potential of all six extracts of Desmostachya bipinnata Stapf (Kush) using test involving inhibition of DPPH activities. The highest antioxidant activity of acetone extract was noticed at $\mathrm{IC}_{50}$ (Inhibition concentration at $50 \%$ ) of $17.42 \mu \mathrm{g} / \mathrm{ml}$ followed by methanol extract at $\mathrm{IC}_{50}$ of $25.83 \mu \mathrm{g} / \mathrm{ml}$ compared to those of ascorbic acid $(7.5 \mu \mathrm{g} / \mathrm{ml})$. Current studies indicated that plant root extracts possessed moderate antimicrobial activities and good antioxidant activity. So our findings revealed that the acetone extract of Desmostachya bipinnata Stapf (Kush) possess antioxidant properties and could serve as free radical inhibitors or scavenger or, acting possibly as natural antioxidants.

\section{Introduction}

At present, herbal medicine represents one of the most important fields of traditional medicine all over the world. To promote the proper use of herbal medicine and to determine their potential as sources for new drugs, it is essential to study medicinal plants having folklore reputation in a more intensified way. A huge number of the world's population have exclusively been used medicinal plants for centuries as remedies for human diseases (Nostro et al., 2000; Arokiyaraj et al., 2008). Knowledge of the chemical constituents of plants is desirable because such information will be value for the synthesis of complex chemical substances. Phytochemical screening of plants has revealed the presence of numerous chemicals including alkaloids, flavonoids, tannins, 
steroids, glycosides and saponins. Secondary metabolites from plant serve as defense mechanisms against predation by many microorganisms, insects, herbivores and oxidative stress (Cowan, 1999).

Oxidative stress induced ROS and free radicals are believed to be major cause of physiological disorders like Alzheimers, Parkinson's, arthritis, atherosclerosis, coronary heart diseases, emphysema, gastric ulcer, diabetes mellitus, cirrhosis, aging and cancer.

Presence of a multitudes of vitamins, polyphenols, flavonoids, tannins and phenolic acids in natural extracts of vegetables, fruits, herbs, spices and medicinal plants and inverse relationship between these natural antioxidants and the risk of oxidative diseases has caused spurt in extensive research and have been described to possess biological activities such as antioxidant, antiinflammatory, oestrogenic, cytotoxic, antitumor (Harborne et al., 1992).

Desmostachya bipinnata Stapf (Family: Poaceae) locally named English nameSacrificial Grass (smaller var.), Ayurvedic name- Kusha, Suuchyagra, Yagyabhuushana, Kshurapatra, Siddha/Tamil name-Tharubai, that is widely distributed throughout the plains of India in hot and dry places. The roots of plant are cooling, diuretic, galactagogue, emollient, aphrodisiac, astringent, used for menorrhagia, diarrhea, dysentery, skin disease, renal and vesical calculi, asthma, jaundice, dysurea, bleeding piles, burning sensation, cystitis, dispesis, vaginal discharges and erysipelas (The Ayurvedic Pharmacopoeia of India, Government of India Ministry of Health and Family Welfare Department of Ayush).

In present research work, we have made an attempt to examine the preliminary phytochemical test, antimicrobial and antioxidant activity of the different six extracts of roots of Desmostachya bipinnata Stapf.

\section{Materials and Methods}

\section{Collection of plant material}

The roots of Desmostachya bipinnata Stapf were collected from Junagadh region (Fig. 1). Using standard taxonomical methods, Dept. of Botany, JAU, Junagadh provided information regarding identification of the plant's parts used in this work. The samples were then separated and cleaned from impurities.

\section{Extraction of plant material}

The roots of plants were separated and washed with tap water to remove the impurities. The roots were cut into small pieces and were subjected to air dry for 10 days. The air-dried samples were then transferred into oven for drying and then were crushed. Dried powder of experimental material was extracted in soxtherm apparatus successively with hexane, ethyl acetate, acetone, methanol and water, respectively due to their nature of polarity. $130 \mathrm{ml}$ solvent required per $10 \mathrm{gm}$ dried powder of experimental material. Plant materials were extracted in the mixture of methanol and water in 9:1 ratio. Desired sample was weighted and dissolved in a reasonable amount of the corresponding solvent (typically about $1.5 \mathrm{ml}$ for every $10 \mathrm{mg}$ of sample). The solution was filtered through a 0.2 micron filter to ensure that no particles were present in the solution. The method for soxtherm has been selected as per the table 1 .

After extraction, the hexane, ethyl acetate, acetone, methanol, water and methanol: water extracts were concentrated using rotary evaporator and dried in hot air oven at $500{ }^{\circ} \mathrm{C}$ to get the solid mass and remaining sample 
weighted yield was collected after lyophilisation for further use. Extractive yield in different solvent was calculated in \%.

\section{Preliminary phytochemical screening}

The extracts were screened for primary phytochemicals (Raja et al., 2011; Reddy et al., 2012) with minor modifications. Procedure for the qualitative preliminary phytochemical screening is given in table 2 .

\section{Antimicrobial activity}

The antimicrobial activity of the crude extracts were determined by the agar well diffusion method (Bauer et al., 1966) against the microbial strains given in table 5 whereas Kanamycin $(30 \mu \mathrm{g} / \mathrm{ml})$ and fluconazole $(30$ $\mu \mathrm{g} / \mathrm{ml}$ ) were used as the standard for antibacterial and antifungal respectively. The extracts were dissolved separately in DMSO concentration of $100 \mu \mathrm{g} / \mathrm{ml}$ and carefully load into the well. The plates were then incubated at $37^{\circ} \mathrm{C}$ for $24 \mathrm{~h}$ to allow maximum growth of the organisms. The test material having antimicrobial activity inhibited the growth of the microorganisms and a clear, distinct zone of inhibition was visualized surrounding the well. The antimicrobial activity of the test agents was determined by measuring the diameter of zone of inhibition expressed in $\mathrm{mm}$.

\section{Collection of microorganism}

Escherichia coli, Salmonella, Vibrio, Aspergillus niger and Aspergillus flavus were provided by Department of Biotechnology, Junagadh Agricultural University, Junagadh. Microorganisms were stored at $4{ }^{\circ} \mathrm{C}$ on Nutrient agar slant and potato dextrose agar slant before use.

\section{In vitro antioxidant assays}

The DPPH (2, 2-Diphenyl-1-Picrylhydrazyl) free radical scavenging activity was measured by the modified method of McCune and Johns (2002). The reaction mixture $(3.0 \mathrm{ml})$ consisted of $1.0 \mathrm{ml}$ DPPH in methanol $(0.3$ $\mathrm{mM}), 1.0 \mathrm{ml}$ methanol and $1.0 \mathrm{ml}$ different concentrations of the extracts were incubated in dark for $10 \mathrm{~min}$, after which the absorbance was measured at $517 \mathrm{~nm}$ against blank. For control, $1.0 \mathrm{ml}$ of methanol was used in place of extract. Ascorbic acid was used as positive control (Yamaguchi et al., 1998). Percentage of inhibition was calculated using the formula:

Inhibition $(\%)=\left(\mathrm{A}_{0}-\mathrm{A}_{1} / \mathrm{A}_{0}\right) \times 100$

Where, $\mathrm{A}_{0}$ is the absorbance of control and $\mathrm{A}_{1}$ is the absorbance of sample.

In order to calculate $\mathrm{IC}_{50}$ value, plant extract solution in methanol was further diluted and tested for DPPH assay to find out 50\% inhibition. $\mathrm{IC}_{50}$ value was calculated by graph method.

\section{Results and Discussion}

\section{Extractive yield}

Many researchers reported influence of different extraction solvents on the content of natural compounds in extracts. Efficiency of solvents and methods are strongly dependent on plant matrix used (Das et al., 2010). The extractive Yields of dried root powder of plants are given in table 3. Highest solubility of metabolites was found in water extract followed by methanol: water and methanol.

\section{Preliminary phytochemical analysis}

Maximum amount of phenol, glycosides, Steroids and flavanoids were found in, respectively present in moderate amount in Methanol: Water (90:10) extracts and methanol extracts. Saponins, terpenoids, triterpenoids and fat were absent in Methanol: Water (90:10) extracts. Water extracts of 
Desmostachya bipinnata Stapf had moderate amount of Tannins, alkaloids, and carbohydrates. Acetone extracts had maximum amount of glycosides, terpenoids. terpenoids, triterpenoids, phenol, glycosides and steroids were present in moderate amount in ethyl acetate extract. Hexane extract had maximum amount of Fat and fixed oils. The phytochemical screenings of different extracts of Desmostachya bipinnata Stapf are listed in table 4.

Table.1 Soxtherm method set up for extraction in different solvents

\begin{tabular}{|l|l|l|l|}
\hline \multicolumn{1}{|c|}{ Solvent } & $\begin{array}{c}\text { Temperature } \\
\left({ }^{\circ} \mathbf{C}\right)\end{array}$ & $\begin{array}{c}\text { T- Class } \\
\text { Value }\end{array}$ & $\begin{array}{l}\text { Extraction } \\
\text { time ( Hrs) }\end{array}$ \\
\hline Hexane & 75 & 200 & $6: 30$ \\
\hline $\begin{array}{l}\text { Ethyl } \\
\text { Acetate }\end{array}$ & 85 & 200 & $6: 30$ \\
\hline Acetone & 65 & 200 & $6: 45$ \\
\hline Methanol & 73 & 300 & $11: 30$ \\
\hline Water & 105 & 300 & $10: 30$ \\
\hline
\end{tabular}

Table. 2 Procedure for the qualitative preliminary phytochemical screening

\begin{tabular}{|c|c|c|c|c|}
\hline Sr. No. & Phytochemical & Procedure & $\begin{array}{c}\text { Nature of color } \\
\text { change }\end{array}$ & Inference \\
\hline 1. & Flavonoids & Substance $+10 \% \mathrm{NaOH}$ & Green brown & Present \\
\hline 2. & Saponin & Substance shake in water & Frothing present & Present \\
\hline 3. & Steroids & $0.5 \mathrm{ml}$ of extract $+1 \mathrm{ml}$ conc. $\mathrm{H}_{2} \mathrm{SO}_{4}$ & Wine red color & Present \\
\hline 4. & Quinone & Substance + conc. $\mathrm{HCl}$ & Green color & Present \\
\hline 5. & Cellulose & Extract +Iodine followed by $\mathrm{H}_{2} \mathrm{SO}_{4}$ & Brown color & Present \\
\hline 6. & Terpenoids & $\begin{array}{c}\text { Substance }+2 \mathrm{ml} \text { chloroform + conc. } \\
\mathrm{H}_{2} \mathrm{SO}_{4}\end{array}$ & $\begin{array}{l}\text { Reddish brown color } \\
\text { at the interface }\end{array}$ & Present \\
\hline 7. & Triterpenes & $\begin{array}{l}0.5 \mathrm{ml} \text { of extract }+ \text { few drops of acetic } \\
\text { anhydride }+1 \mathrm{ml} \text { conc. } \mathrm{H}_{2} \mathrm{SO}_{4} \text { from the } \\
\text { side of test tube }\end{array}$ & $\begin{array}{c}\text { Red ring at the } \\
\text { junction }\end{array}$ & Present \\
\hline 8. & Cardiac glycosides & $\begin{array}{c}\text { Substance }+2 \mathrm{ml} \text { glacial acetic acid }+1 \\
\text { drop of } \mathrm{FeCl}_{3}+1 \mathrm{ml} \text { of conc. } \mathrm{H}_{2} \mathrm{SO}_{4} \text { from } \\
\text { the wall of test tube }\end{array}$ & $\begin{array}{l}\text { Reddish brown ring a } \\
\text { of the two sol }\end{array}$ & $\begin{array}{l}\text { thePresetion } \\
\text { ents }\end{array}$ \\
\hline 9. & Phenol & Substance + alcohol $+\mathrm{FeCl}_{3}$ & Greenish yellow & Present \\
\hline 10. & Tannin & $\begin{array}{c}0.5 \mathrm{~g} \text { substance }+20 \mathrm{ml} \mathrm{H}_{2} \mathrm{O} \text { is boiled. + } \\
0.1 \% \mathrm{FeCl}_{3}\end{array}$ & Brownish green & Present \\
\hline 11. & Alkloids & $\begin{array}{c}2 \mathrm{ml} \text { test solution }+2 \mathrm{~N} \mathrm{HCl}+\text { Mayer's } \\
\text { reagent }\end{array}$ & $\begin{array}{c}\text { Yellowish orange } \\
\text { precipitate }\end{array}$ & Present \\
\hline 12. & Lignans & $\begin{array}{c}0.5 \mathrm{ml} \text { extract }+2 \mathrm{ml} \text { of } 2 \%(\mathrm{~V} / \mathrm{V}) \\
\text { furfuraldehyde }\end{array}$ & Red color & Present \\
\hline 13. & Carbohydrate & $\begin{array}{l}\text { Crude extract }+ \text { shake }+2 \mathrm{ml} \text { conc. } \mathrm{H}_{2} \mathrm{SO}_{4} \\
\text { from the side of test tube }\end{array}$ & $\begin{array}{l}\text { Violet ring at the } \\
\text { junction }\end{array}$ & Present \\
\hline 14. & $\begin{array}{l}\text { Amino acid, } \\
\text { Protein }\end{array}$ & $\begin{array}{l}\text { Crude extract boiled with } 2 \mathrm{ml} 0.2 \% \\
\text { ninhydrin }\end{array}$ & Violet color & Present \\
\hline 15. & Fat and fixed oil & Substance + Sudan III & Shining orange color & Present \\
\hline
\end{tabular}


Table.3 Extractive yield (\%w/w) of roots of Desmostachya bipinnata Stapf (Kush)

\begin{tabular}{|c|c|}
\hline Plant & $\begin{array}{c}\text { Desmostachya bipinnata } \\
\text { Stapf } \\
(\text { Kush })\end{array}$ \\
\hline Hexane & $0.5 \%$ \\
\hline Ethyl acetate & $0.493 \%$ \\
\hline Acetone & $0.28 \%$ \\
\hline Methanol & $8.49 \%$ \\
\hline Water & $10.71 \%$ \\
\hline $\begin{array}{c}\text { Methanol: } \\
\text { Water (90:10) }\end{array}$ & $9.14 \%$ \\
\hline
\end{tabular}

Table.4 The qualitative preliminary phytochemical screening of Desmostachya bipinnata Stapf (Kush)

\begin{tabular}{|c|c|c|c|c|c|c|c|}
\hline $\begin{array}{c}\text { No. } \\
\text { of } \\
\text { tests }\end{array}$ & Tests & HEXANE & $\begin{array}{c}\text { ETHYLE } \\
\text { ACETATE }\end{array}$ & ACETONE & METHANOL & WATER & $\begin{array}{c}\text { METHANOL:WATER } \\
(90: 10)\end{array}$ \\
\hline 1 & FLAVONOIDS & - & + & + & $+t$ & + & + \\
\hline 2 & SAPONINS & - & - & - & - & + & - \\
\hline 3 & STEROIDS & + & $+t$ & + & - & - & $+t$ \\
\hline 4 & QUINONE & - & - & - & + & - & + \\
\hline 5 & CELLULOSE & - & - & - & - & - & - \\
\hline 6 & TERPENOIDS & + & $+t$ & t+t & - & - & - \\
\hline 7 & TRITERPENOIDS & + & ++ & $+t$ & - & - & - \\
\hline 8 & GLYCOSIDES & + & $+t$ & $+t+$ & t+t+ & + & $++t$ \\
\hline 9 & PHENOLS & + & $+t$ & $+t$ & +++ & $+t$ & $++t$ \\
\hline 10 & TANNINS & - & - & - & + & $+t$ & + \\
\hline 11 & ALKALOIDS & - & - & - & - & + & + \\
\hline 12 & LIGNANS & - & - & - & - & - & - \\
\hline 13 & CARBOHYDRATES & - & - & - & + & $+t$ & - \\
\hline 14 & $\begin{array}{l}\text { PROTEINS \& } \\
\text { AMINO ACIDS }\end{array}$ & - & - & - & + & - & + \\
\hline 15 & FAT \& FIXED OILS & $++t$ & + & - & - & - & - \\
\hline
\end{tabular}

Presence $=+$, Moderate Presence $=++$, considerable amount $=+++$, and Absent $=-$ 
Table.5 Antimicrobial activity of different extracts of Desmostachya bipinnata Stapf

\begin{tabular}{|c|c|c|c|c|c|}
\hline \multirow{2}{*}{$\begin{array}{c}\text { Plant root } \\
\text { Extracts }\end{array}$} & \multicolumn{5}{|c|}{ ZONE OF INHIBITION (mm) } \\
\cline { 2 - 6 } & Escherichia coli & Salmonella & Vibrio & $\begin{array}{c}\text { Aspergillus } \\
\text { niger }\end{array}$ & $\begin{array}{c}\text { Aspergillus } \\
\text { Flavus }\end{array}$ \\
\hline Hexane & - & - & 7 & - & - \\
\hline Ethyl acetate & - & 7 & 6 & 6 & - \\
\hline Acetone & 7 & - & - & 8 & - \\
\hline Methanol & 9 & - & - & 11 & - \\
\hline Water & - & - & - & 12 & - \\
\hline Methanol: water (90:10) & - & - & - & 11 & 8 \\
\hline Kanamycin & 14 & 13 & 13 & - & - \\
\hline Fluconazole & - & - & - & 14 & 12 \\
\hline
\end{tabular}

Table.6 The antioxidant activity of various extracts of Desmostachya bipinnata Stapf

\begin{tabular}{|c|c|c|}
\hline Plant & Solvent name & IC $_{\mathbf{5 0}}(\boldsymbol{\mu} \mathbf{g} / \mathbf{m l})$ \\
\hline \multirow{4}{*}{$\begin{array}{c}\text { Kush (Desmostachyabipinnata } \\
\text { Stapf) rootExtract }\end{array}$} & Hexane & - \\
\cline { 2 - 3 } & Ethyl acetate & - \\
\cline { 2 - 3 } & Acetone & $\mathbf{1 7 . 4 2}$ \\
\cline { 2 - 3 } & Methanol & 25.83 \\
\cline { 2 - 3 } & Water & - \\
\cline { 2 - 3 } & Methanol: water & - \\
& Ascorbic acid & 7.5 \\
\hline
\end{tabular}

Fig.1 Morphology and roots of Desmostachya bipinnata Stapf

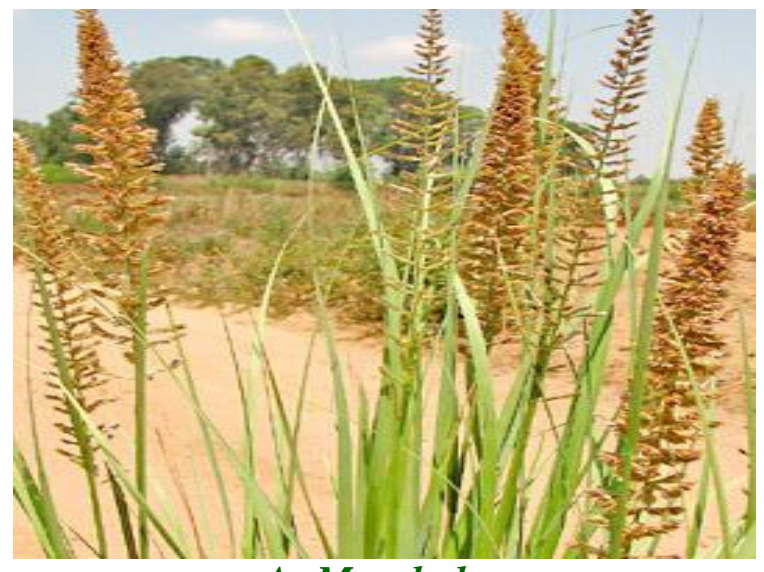

A: Morphology

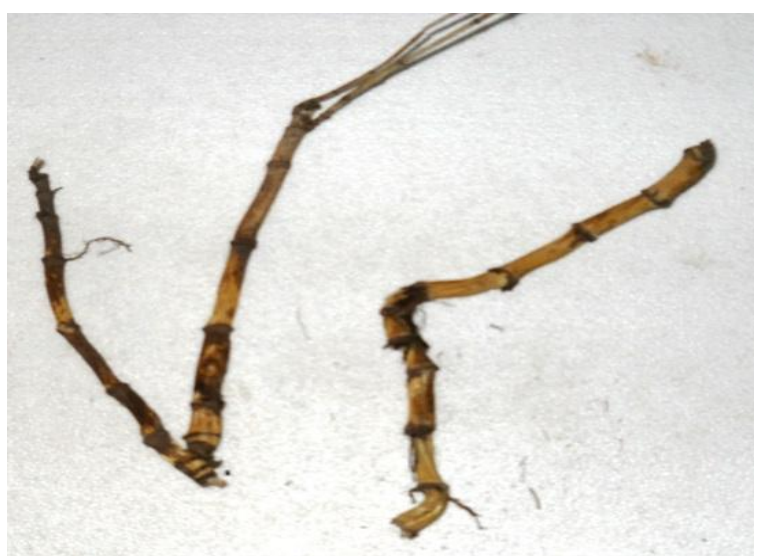

B: Root 
Fig.2 Antioxidant activity of standard ascorbic acid

\section{Standard Ascorbic acid}

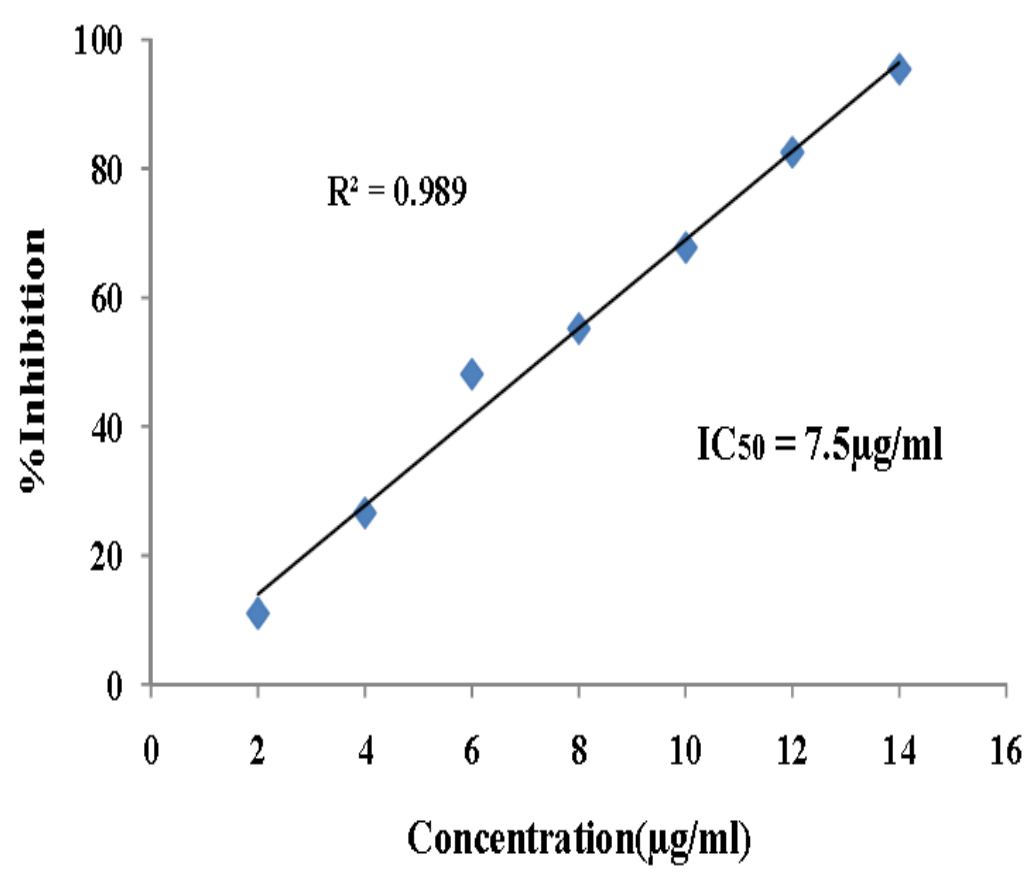

Fig.3 Antioxidant activity of acetone extract

\section{Acetone extract of Kush (Desmostachya bipinnata Stapf) root}

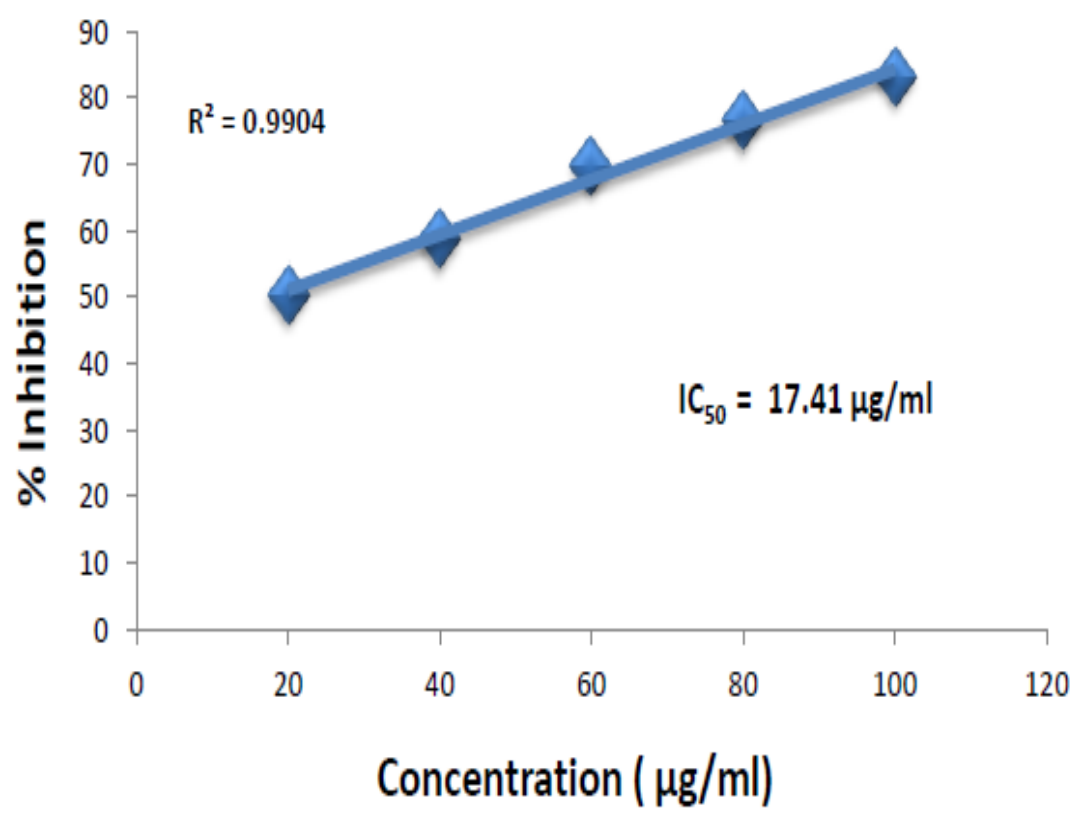


Fig.4 Antioxidant activity of methanol extract

\section{Methanol extract of Kush (Desmostachya bipinnata Stapf) root}

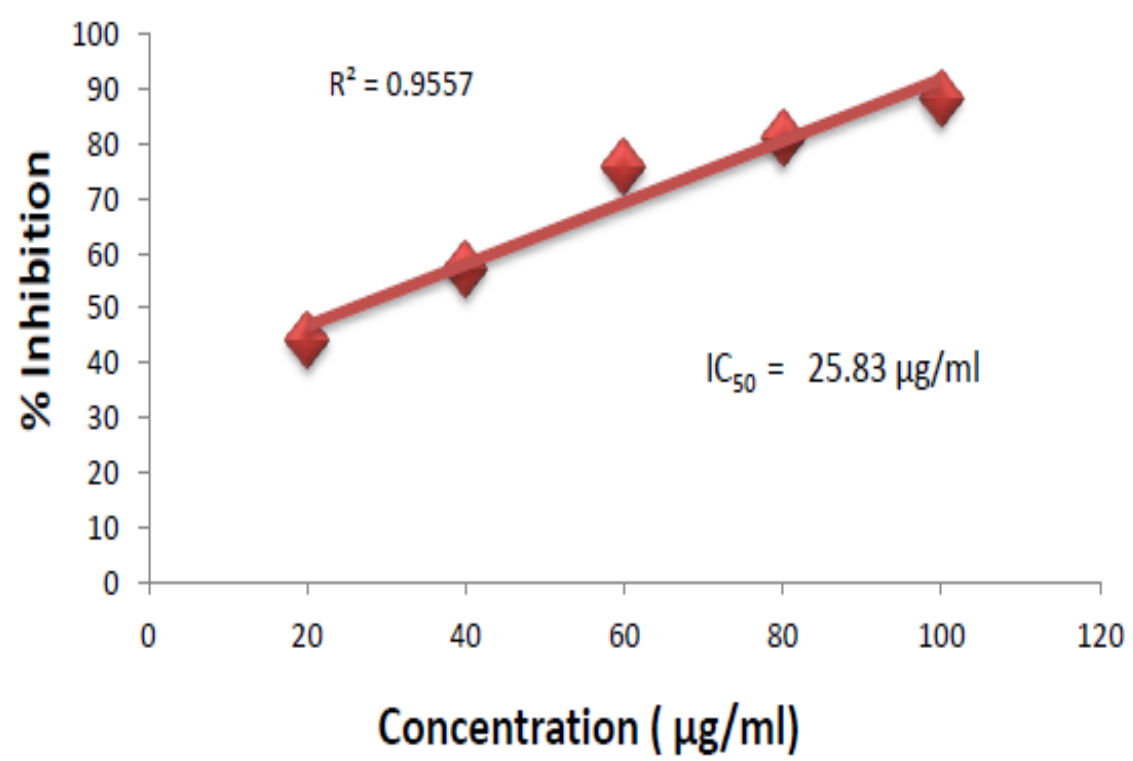

\section{Antimicrobial activity}

The extracts of the sample were tested for antibacterial activity against a three different gram positive and gram negative bacteria. Standard antibiotic disk of kanamycin at $30 \mu \mathrm{g} / \mathrm{ml}$ was used for comparison purposes. The extracts showed antibacterial activity against limited number of the test organisms. The results of the antibacterial activity measured in terms of diameter of zone of inhibition in $\mathrm{mm}$ are showed in table 5. One concentration of the extracted sample 100 $\mu \mathrm{g} / \mathrm{ml}$ was used for antibacterial activity.

The extracts of the sample were tested for antifungal activity against two fungi. Standard of fluconazole at $30 \mu \mathrm{g} / \mathrm{ml}$ was used for comparison purposes. The extracts Showed little antifungal activity against the test organisms. The results of antifungal activity Measured in terms of diameter of zone of inhibition (ZOI) are shown in table 5.

\section{Antioxidant activity by DPPH method}

The DPPH scavenging activity of the some extracts were significantly good compared to those of ascorbic acid and it was evident that the extract did show the proton-donating ability and could serve as free radical inhibitors as antioxidants (Kai et al., 2007). The antioxidant potential on plants has been found a correlation between the phenolic content and the antioxidant activity (Zahin et al., 2009). The antioxidant potential of acetone and methanol extract have the DPPH scavenging activity, acetone extract has maximum $\mathrm{IC}_{50} \quad(17.42 \mu \mathrm{g} / \mathrm{ml})$. Methanol extract has lower scavenging activity $\left(\mathrm{IC}_{50}\right.$ $25.83 \mu \mathrm{g} / \mathrm{ml}$ ) compared to acetone extract (Fig. 2-4). Study showed that the capability of the extracts to scavengering free radicals, indicating that they may be useful therapeutic agents for treating radical-related pathological damage. The antioxidant activity of various extracts of Desmostachya bipinnata Stapf are given in table 6 . 
From above study it was clearly evident that the acetone extract of Desmostachya Bipinnata Stapf (Kush) possess antioxidant properties and could serve as free radical inhibitors or scavenger or, acting possibly as natural antioxidants.

\section{Acknowledgment}

This work is supported by food testing laboratory, Department Of Biochemistry and Biotechnology, Junagadh Agricultural University, Junagadh

\section{References}

Arokiyaraj, S., Radha, R., Martin, S. and Perinbam, K. 2008. Indian J. Sci. Technol., 1(6): 1-4.

Bauer, A.W., Kirby, W.M., Sherris, J.C. and Turck, M. 1966. American J. Clin. Pathol., 45: 493-496.

Cowan, M.M. 1999. Clin. Microbiol. Rev., 12: 564-582.

Das, K., Tiwari, R.K. and Shrivastava, D.K.
2010. J. Med. Plan. Res., 4(2): 104-111.

Harborne, J.B., William, E.A. 1992. Phytochem., 55: 481-501.

Kai, M., Klaus, H.V., Sebastian, L., Ralf, H., Andreas, R., and Ulf-Peter, H. 2007. Sensors, 7: 2080-2095.

McCune, L.M. and Johns, T. 2002. J. Ethnopharma., 82: 197-205.

Nostro, A., Germano, M.P., D'angelo, V., Marino, A. and Cannatelli, M.A. 2000. Lett. Appl. Microbiol., 30(5): 379-84.

Raja, A.V. and Same, K. 2011. Int. Res. J. Pharm., 2(10): 42-43.

Reddy, M.N. and Mishra, G.J. 2012. Int. J. Phytopharma, 3(2): 147-151.

The Ayurvedic Pharmacopoeia of India, Government of India Ministry of Health and Family Welfare Department of Ayush, New delhi. (API)

Yamaguchi, T., Takamura, H., Matoba, T. and Terao, J. 1998. Biosci. Biotechnol. Biochem., 62: 1201-1204.

Zahin, M., Aqil, F. and Ahmad, I. 2009. Int. J. Pharm. Pharma. Sci., 1(1): 88-95.

\section{How to cite this article:}

Joshi, K.B., M.K. Mandavia and Golakiya, B.A. 2017. Comparative Study of Phytochemical Analysis, Antimicrobial and Antioxidant Activity of Different Root Extracts of Desmostachya bipinnata Stapf (Kush). Int.J.Curr.Microbiol.App.Sci. 6(5): 129-137.

doi: http://dx.doi.org/10.20546/ijcmas.2017.605.016 